\title{
Effect of Organic and Inorganic Fertilizer Doses on Growth and Yield of Lentil under Cold Arid Conditions of Ladakh
}

\author{
Kaneez Fatima, S.A. Ganie*, Yogesh Kumar, T.H. Masoodi and Ali Shah \\ High Mountain Arid Agriculture Research Institute, Leh (SKUAST-Kashmir), India \\ *Corresponding author
}

\section{A B S T R A C T}

\begin{tabular}{|l|}
\hline K e y w or d s \\
Lentil, Organic, \\
inorganic, Seed yield, \\
NPK and FYM
\end{tabular}

To find out the effect of organic and inorganic fertilizers on growth and yield of lentil an experiment was conducted at High Mountain Arid Agriculture Research Institute, Leh (SKUAST-Kashmir) during Kharif season 2017. The experiment consists of one genotype of lentil Shalimar masoor-1 laid in Randomized Block Design (RBD) with three replications and seven treatment levels. The plot size of $2 \times 2 \mathrm{~m}$ was used in this experiment. The results showed that combination of NPK+FYM recorded significantly higher biological yield than NPK used alone. The data showed that NPK 50:70:30+4t FYM recorded significantly higher biological yield than control. The study also indicated that significantly highest seed yield $(6.90 \mathrm{q} / \mathrm{ha})$ was obtained with application of NPK 50:70:30+4tFYM/ha rather than other applications of organic and inorganic and control. This treatment also shows maximum number of pods per plants. Thus our study shows the positive impact of compost application and chemical fertilizer use.

\section{Introduction}

Lentil is an important cool season food legume grown under marginal Lands by resilient poor farmers. It can tolerate frost \& severe winter, hence well suited to the climatic conditions of Ladakh valley. It has good scope to be grown as an intercrop in young orchards. Lentil (Lens culinaris ssp. culinaris Medikus) is a diploid $(2 n=2 x=14)$ self-pollinating legume crop with a genome size of approximately $4 \mathrm{Gbp}$ (Arumuganathan and Earle, 1991). Lentil is a Latin word that describes exactly the shape of the seed of a cultivated legume now known as Lens culinaris, a name given by the German botanist Medikus in 1787 (Cubero, 1981). In the Indian subcontinent, lentils have been grown as a green manure in one-year rotation with cereals, especially rice (Saxena and Hawtin, 1981). Additionally, lentils can also be used as a livestock feed as they have high content of protein and crude fibre (Kay, 1979).

It is the second most important cool season food legume after chickpea. Being grown for over 8,000 years (Dhuppar et al., 2012), it is considered as one of the early domesticated species (Cokkizgin and Munqez, 2013). It is one of the principal pulse crops cultivated in semi-arid region of the world, particularly in India sub-continent and the dry areas of Middle East (Malik, 2005). Lentil is predominantly grown in Asia which accounts 
for 80 per cent of global area and 75 per cent of world production. It occupies second place among the winter pulses after chickpea in the country covering an area of $1.48 \mathrm{~m}$ ha with a production of 1.03 million tonnes (Anonymous, 2011). The major lentil producing states are Uttar Pradesh, Madhya Pradesh, Bihar, West Bengal, Rajasthan and Assam. Lentil is a rich source of carbohydrate, protein, vitamins, minerals (K, P, Fe, Zn), dietary fibre with high energy value (De Almeida Costa et al., 2006) and it contains substantial amount of oleic, linoleic and palmitic acid (Roy et al., 2009). Lentil seeds are also a good source of essential minerals like calcium, phosphorous, iron and vitamin B. Lentil seeds contains about $25 \%$ protein, $0.7 \%$ fat, $2.1 \%$ minerals, $0.7 \%$ fibre and $59 \%$ carbohydrate.

It is estimated that Indian population will be nearly 1.35 billion by 2020 and will require 30 million tonnes of pulses as against the present production of 16.5 million tons (Anonymous, 2007). Globally, lentil is cultivated as rainfed crop in more than 52 countries covering about $3.85 \mathrm{~m}$ ha area with a production of $3.59 \mathrm{~m} \mathrm{t}$ (Erskine et al., 2011). Canada, India, Turkey, Australia, U.S.A., Nepal, China, and Ethiopia are the major contributors (Reda, 2015). The area under lentil in Jammu and Kashmir is 26.6 thousand ha and its production is about 14.3 thousand tonnes which is low as compared to the national average. The average yield in Jammu and Kashmir is $538 \mathrm{~kg} / \mathrm{ha}$. It can easily fit in doubling cropping in rain fed areas and paddy lands having good drainage. In Jammu and Kashmir, lentil is a relatively minor pulse crop as it is grown mainly on subtropical foothill soils with low fertility and water holding capacity. Locally known as Masoor, Lentil is an important cool season food legume grown under marginal lands by resource-poor farmers. Lentil is a very important pulse crop grown in Ladakh region. It can tolerate frost and severe winter, hence well suited to the climate conditions of Ladakh valley. It has good scope to be grown as an inter-crop in young orchards. Lentil is the important pulse crop of the farmers of Ladakh region as it is hardy in character and grows on minimum irrigation levels. With its demand area in the region it has become necessary to investigate the best proportion levels of chemical and organic fertilizers for obtaining highest productivity. Under cold arid conditions integrated use of chemical fertilizers with organic compost will increase the lentil production and soil health. Keeping in view the above concept, the present experiment was aimed to study the effect of chemical fertilizers and FYM on growth and yield potential of lentil under cold arid conditions of Ladakh.

\section{Materials and Methods}

The experiment was conducted at High Mountain Arid Agricultural Institute Leh, SKUAST-Kashmir (J\&K) India during Kharif season 2017. The experimental site is located at $12500 \mathrm{ft}$ above the mean sea level. The experiment was laid out in a randomized block design with three replications. The experiment comprised of seven treatments which include

$$
\begin{aligned}
\mathrm{T} 1 & =(\text { control }) \\
\mathrm{T} 2 & =(30: 60: 30 \mathrm{NPK} / \mathrm{ha}) \\
\mathrm{T} 3 & =(30: 60: 30 \mathrm{NPK}+1.5 \mathrm{t} \mathrm{FYM} / \mathrm{ha}) \\
\mathrm{T} 4 & =(30: 60: 30 \mathrm{NPK} / \mathrm{ha})+2 \mathrm{t} \mathrm{FYM} / \mathrm{ha}) \\
\mathrm{T} 5 & =(40: 60: 30 \mathrm{NPK} / \mathrm{ha}+2.5 \mathrm{t} \mathrm{FYM} / \mathrm{ha}) \\
\mathrm{T} 6 & =(50: 70: 30 \mathrm{NPK} / \mathrm{ha})+3 \mathrm{t} \mathrm{FYM} / \mathrm{ha} \\
\mathrm{T} 7 & =(50: 70: 30 \mathrm{NPK}+4 \mathrm{t} \mathrm{FYM} / \mathrm{ha}
\end{aligned}
$$

As Ladakh region of Jammu and Kashmir is a cold arid zone, so the characteristics of its soil would be quite different than those of other zones due to difference in climate, topography, vegetation and rocks. The soil of experimental site was loamy sand in texture. The Lentil variety Shalimar Masoor- I was sown at the rate of $40 \mathrm{~kg} / \mathrm{ha}$. All agronomic 
practices were kept uniform and normal for all treatments. The data on plant height $(\mathrm{cm})$, number of nodules per plant, days to maturity, number of pods per plant, number of seeds per pod, 1000- seed weight (g), seed yield and biological yield were recorded during the course of study by following standard procedure. Full dose of phosphorus and potassium and basal dose of nitrogen were applied. The observations were recorded on five randomly selected plants from each plot in each replication. The unit plot size was $2 \mathrm{~m}$ $\times 2 \mathrm{~m}$. The variety of lentil used for experiment was Shalimar Masoor-1.

Seeds were sown in lines at a spacing of 25 $\mathrm{cm} \times 10 \mathrm{~cm}$ inter and intra row. The chemical fertilizers viz. urea, single super phosphate and muriate of potash were used as source of nitrogen, phosphorus and potassium, respectively. The data obtained in respect of various observations were statistically analysed by the method described by Cochran et al., 1967. The significance of " $F$ " and " $t$ " was tested at 5 per cent level of significance.

\section{Results and Discussion}

The field experiment was conducted during kharif season of 2017at experimental farm of High Mountain Arid Agriculture Research Institute of Leh, SKUAST-Kashmir, J\&K, India. The soil of the experimental site was loamy sand in texture. The experiment was laid in a randomised block design with seven treatments replicated thrice.

\section{Growth attributes}

Growth parameters like plant height, number of branches/ plant, number of nodules/plant and days to maturity were differed significantly (Table 1). Highest plant height $(29.20 \mathrm{~cm})$ was recorded from the treatment 50:70:30 NPK/ha +4 t FYM /ha. However, the values obtained from the treatments T5 $(28.25$ $\mathrm{cm})$ and T6 $(28.75 \mathrm{~cm})$ were found statistically at par with T7. The lowest plant height $(20.25 \mathrm{~cm})$ was recorded from the treatment T1 (control). The significant increase in plant height with these treatments might be due to greater availability and steady release of nutrients. Kundu et al., (2010) opined that adequate supply of phosphorus influenced the plant height. According to Singh et al., (2003) phosphorus increased Nfixing capacity of legumes and also increased the chlorophyll content. Significant increase in the plant height in lentil with the application of nitrogen has also been reported earlier by Mohammad Janloo et al., (2009) and Niri et al., (2010).

Highest number of branches plant-1 (14.50) were recorded with treatment T7 (50:70:30 $\mathrm{NPK} / \mathrm{ha}+4 \mathrm{t} \mathrm{FYM} / \mathrm{ha}$ ). However, the values obtained from the treatments T6 (50:70:30 NPK/ha+ 3t FYM/ha) (13.90) and T5 (40:60:30 NPK/ha+ 2.5t FYM/ha) were statistically at par with treatment $\mathrm{T} 7$. The least number of branches/plant (8.20) were obtained in control in which neither organic nor inorganic fertilizers were used. The highest number of branches recorded might be due to greater availability of nutrients. Babu et al., (2007) reported that slow release of nutrients from the organic sources at later stages of crop growth had resulted in increased number of branches. Number of branches increased with the supply of phosphorus is in accordance with the finding of Sharma and Sharma (2004). Number of nodules/plant (7.28) were recorded highest in treatment T7 (50:70:30 NPK/ha+ 4t FYM/ha). The least number of nodules were observed in control (6.12). Earlier Mandal and Majumdar (2001) also reported increase in the nodule number with increase in the nitrogen doses. The data also revealed that the maturity stage of lentil was significant different in different treatments. These results are in close conformity with the results of Mohammad Janloo et al., (2009). 
Table.1 Effect of organic and inorganic fertilizers on the growth of lentil

\begin{tabular}{|l|l|l|l|l|}
\hline Treatment & $\begin{array}{l}\text { Plant } \\
\text { height } \\
(\mathrm{cm})\end{array}$ & $\begin{array}{l}\text { No. of } \\
\text { branches / } \\
\text { plant }\end{array}$ & $\begin{array}{l}\text { No. of } \\
\text { nodules / } \\
\text { plant }\end{array}$ & $\begin{array}{l}\text { Days to } \\
\text { maturity }\end{array}$ \\
\hline $\begin{array}{l}\text { T1(control) } \\
20.25\end{array}$ & 8.20 & 6.12 & 143.33 \\
\hline $\begin{array}{l}\text { T2(30:60:30NPK/ha) } \\
\text { T3(30:60:30NPK+1.5 } \\
\text { t FYM/ha) }\end{array}$ & 24.36 & 10.30 & 6.27 & 145.52 \\
\hline $\begin{array}{l}\text { T4(30:60:30NPK/ha) } \\
+ \text { 2t FYM/ha) }\end{array}$ & 26.25 & 11.10 & 6.38 & 146.33 \\
\hline $\begin{array}{l}\text { T5(40:60:30NPK/ha } \\
+ \text { 2.5t FYM/ha) }\end{array}$ & 28.25 & 13.40 & 6.67 & 147.25 \\
\hline $\begin{array}{l}\text { T6(50:70:30NPK/ha) } \\
+3 t \text { FYM/ha }\end{array}$ & 28.75 & 13.90 & 6.92 & 147.98 \\
\hline $\begin{array}{l}\text { T7(50:70:30NPK+4t } \\
\text { FYM/ha }\end{array}$ & 29.20 & 14.50 & 7.13 & 148.33 \\
\hline CD at 5\% & 1.42 & 1.13 & 1.23 & 148.56 \\
\hline CV & 4.25 & 3.84 & 4.06 & 1.23 \\
\hline
\end{tabular}

Table.2 Effect of organic and inorganic fertilizers on yield attributes and yield of lentil

\begin{tabular}{|c|c|c|c|c|c|}
\hline Treatment & $\begin{array}{l}\text { No. of } \\
\text { pods } \\
\text { /Plant }\end{array}$ & $\begin{array}{c}\text { No. of } \\
\text { seeds/pod }\end{array}$ & $\begin{array}{l}1000 \text { seed } \\
\text { weight }(\mathrm{g})\end{array}$ & $\begin{array}{l}\text { Biological } \\
\text { yield kgs/ha }\end{array}$ & Yield/ha(qtl) \\
\hline T1(control) & 33.37 & 1.35 & 22.38 & 1033 & 3.88 \\
\hline $\begin{array}{l}\text { T2(30:60:30NP } \\
\text { K/ha) }\end{array}$ & 41.40 & 1.43 & 23.15 & 1225 & 4.25 \\
\hline $\begin{array}{l}\text { T3(30:60:30NP } \\
\text { K+1.5t FYM/ha) }\end{array}$ & 43.69 & 1.52 & 23.50 & 1298 & 4.66 \\
\hline $\begin{array}{l}\text { T4(30:60:30NP } \\
\text { K/ha)+2t } \\
\text { FYM/ha) }\end{array}$ & 45.83 & 1.64 & 23.85 & 1325 & 5.23 \\
\hline $\begin{array}{l}\text { T5(40:60:30NP } \\
\text { K/ha+ 2.5t } \\
\text { FYM/ha) } \\
\end{array}$ & 48.43 & 1.77 & 24.19 & 1418 & 5.65 \\
\hline $\begin{array}{l}\text { T6(50:70:30NP } \\
\text { K/ha)+3t } \\
\text { FYM/ha }\end{array}$ & 51.33 & 1.83 & 24.55 & 1533 & 6.33 \\
\hline $\begin{array}{l}\text { T7(50:70:30NP } \\
\text { K+4t FYM/ha }\end{array}$ & 55.66 & 1.92 & 24.90 & 1615 & 6.90 \\
\hline CD at $5 \%$ & 1.33 & 0.18 & NS & 1.56 & 1.43 \\
\hline $\mathbf{C V}$ & 6.38 & 4.38 & 6.63 & 3.54 & 3.45 \\
\hline
\end{tabular}




\section{Yield attributes}

The data on yield attributes is presented in table 2. The yield attributes like number of pod plant-1, number of seed pod-1, 1000 seed weight $(\mathrm{g})$, biological yield $(\mathrm{kg} / \mathrm{ha})$ and seed yield ( $\mathrm{qtl} \mathrm{ha}^{-1}$ ) differed significantly (Table 2 ). Highest number of pod plant-1 (55.66) was recorded from the treatment (50:70:30 $\mathrm{NPK} / \mathrm{ha}+4 \mathrm{t} \mathrm{FYM} / \mathrm{ha}$ ). However, the values obtained from the treatments T6 (50:70:30 NPK/ha +3t FYM/ha) and T5 (40:60:30 $\mathrm{NPK} / \mathrm{ha}+2.5 \mathrm{t}$ FYM/ha) were found statistically at par having number of pods/plant (51.33) and (48.43) respectively. The lowest number Pods /plant (33.37) was recorded from the treatment control in which no fertilizer was used. Number of seeds/pod was significantly influenced by organic and inorganic fertilizers in lentil. Highest number of seeds/pod (1.92) was recorded from the treatment (50:70:30 NPK/ha +4t FYM/ha), which were followed by treatments $\mathrm{T} 6$ (50:70:30 NPK/ha +3t FYM/ha) and treatment T5 $(40: 60: 30 \quad \mathrm{NPK} / \mathrm{ha} \quad+2.5 \mathrm{t}$ FYM/ha). The lowest number of seeds/pod (1.35) was recorded from control in which no fertilizer was used. There was significant increase in 1000 seed weight (g) as compared to control. Maximum 1000 seed weight $(\mathrm{g})$ was recorded in treatment $\mathrm{T} 7$ (50:70:30 NPK/ha +4t FYM/ha) and least 1000 seed weight $(\mathrm{g})$ was recorded in control. The data on biological yield reveals that maximum yield $(1615 \mathrm{~kg} / \mathrm{ha})$ was obtained from treatment T7 (50:70:30 NPK/ha +4t FYM/ha) which was followed by treatment $\mathrm{T} 6$ (50:70:30 NPK/ha +3t FYM/ha) with biological yield of $(1533 \mathrm{~kg} / \mathrm{ha})$. The least biological yield $(1033 \mathrm{~kg} / \mathrm{ha})$ was obtained in treatment control. Seed yield (kg/ha) was significantly influenced by organic and inorganic fertilizers in lentil. Highest seed yield $(6.90 \mathrm{qtl} / \mathrm{ha})$ was recorded from the treatment T7 (50:70:30 NPK/ha +4t FYM/ha) which was followed by treatments $\mathrm{T} 6$
(50:70:30 NPK/ha +3t FYM/ha) and T5 (40:60:30 NPK/ha +2.5t FYM/ha). The lowest seed yield (3.88 qt1/ha) was recorded from the treatment control in which no fertilizer was used. These findings are in agreement with the findings of Brahmachari et al., (2004, 2008). The results are in conformity with those of Sharma (1999), Mandal and Majumdar (2001), Nakhzeri Moghadam and Ramrodi (2003), Gan et al., (2005), Togay et al., (2005) and Rabbi et al.,(2011) who reported significant increase in seed yield with increase in $\mathrm{N}$ dose.

On the basis of above findings, it can be inferred that application of $50 \mathrm{~kg}$ of nitrogen, $70 \mathrm{~kg}$ of phosphorus and $30 \mathrm{~kg}$ of potash $+4 \mathrm{t}$ FYM per hectare gave highest plant height, no. of branches, number of nodules, number of pod plant ${ }^{-1}$, number of seed/ pod, 1000 seed weight $(\mathrm{g})$, biological yield $(\mathrm{kg} / \mathrm{ha})$ and seed yield (qtl/ ha).

\section{References}

Anonymous. 2007. Hand book of Agriculture. ICAR Publication, New Delhi India

Anonymous. 2011. Project coordinators Report. All India coordinated Research Project on MULLaRp (Rabi crops, 2010-11). Indian instirute of Pulses Research Kanpur. PP.16.

Arumuganathan, K. and Earle E. D. 1991. Nuclear DNA content of some important plant species. Plant Mol. Biol. Rep., 9: 208-218.

Babu, M.V.S., C.M. Reddy, A. Subramanyam, and Balaguravaiah, D. 2007. Effect of integrated use of organic and inorganic fertilizers on soil properties and yield of sugarcane. J. Indian Soc. Soil Sci., 55(2): 161-166.

Brahmachari, K., Kundu, Rajib and Roychoudhury, Suborna. 2008. Effect of different organic and inorganic sources of nutrients and pesticides for 
management of chilli leaf curl disease in coastal saline soil of West Bengal. J. Interacademicia, 12(4): 446-448.

Brahmachari, K., Mondal, Pal. Somnath and Singh, N.N. 2004. Preparation of fishmeal (well decomposed) and its effects on different crops under ricebased cropping system in coastal saline zone of West Bengal. Indian Agriculturist, 48(4): 203-205.

Cochran, WG and Cox G.M. 1967.Planning and analysis of non-experimental studies. In: Proceedings of the Twelfth Conference on the Design of Experiments in Army Research and Testing, ARO-D Report. 67(2):319-36.

Cokkizgin A. and Munqez J. Y. 2013. Lentil origin, cultivation techniques, utilization and advances in transformation. Agricultural Sci., 1(1): $55-62$.

Cubero.J.I.1981. Orgin, taxonomy and domestication In: Lentils (eds C.Webb \& G.C. Hawtin). Commonwealth Agricultural Bureau, Slough, England.

De Almeida Costa, G.E., K. da Silva QueirozMonici, S.M. Pissini Machado Reis and de Oliveira, A.C. 2006. Chemical composition, dietary fibre and resistant starch contents of raw and cooked pea, common bean, chickpea and lentil legumes. Food Chemistry 94, 32 7-330.

Dhuppar P., S. Biyan, B. Chintapalli and Rao S. 2012. Lentil crop production in the context of climate change: an appraisal. Indian Res. J. Exten. Edu., Special Issue: $33-35$

Erskine W., A. Sarkar and Kumar S. 2011. Crops that feed the world 3, Investing in lentil improvement toward a food secure world. Food Security, 3: 127139.

Gan, Y, K.G. Hanson, R.P. Zentner, F. Selles, and McDonald, C.L.2005. Response of lentil to microbial inoculation and low rates of fertilization in the semiarid
Canadian Praities. Canadian Journal of Plant Science, 847-855.

Kay, D.E.1979. Food legumes. Tropical Products Institute, London.

Kundu, R., K. Brahmachari, and Karmaka, S. 2010. Impact of different organic manures in enhancing the growth and productivity office (Oryza sativa) under coastal saline tract of West Bengal. J. Crop \& Weed, 6(2): 42-45.

Malik, R. 2005 Genetic divergence analysis in lentil (Lens culnaris Medik). M.Sc. Thesis, Department of Agricultural Botany, Ch. Charan Singh University, Meerut (U.P.), India. 1pp.

Mandal, K.G. and Majumdar, D.K. 2001. Agro-physiological characteristics of lentil in relation to irrigation, nitrogen and plant density. J. Interacademicia, 5(2): $156-161$

Mohammadjanloo, A.M., A. Gholipoutim, A. Tobeh, and Mostafei H. 2009. Study of effects of different levels of Nitrogen and Potassium on yield and yield components of rainfed Lentil. Plant Ecophysiology, 2: 91-94.

Nakhzeri Moghadam, A., and Ramroudi, M. 2003. Effect of Planting date and nitrogen rate on yield and yield components of lentil. Journal of Agriculture and Resource Science, 9(4): 33- 41.

Niri, H.L., A. Tobeh, A. Gholipouri, R.A. Zakaria, H. Mostafaei, and JammatieSomarin, S. 2010. Effect of nitrogen and phosphorus on yield and protein content of lentil dry land condition. American Eurasian Journal of Agriculture and Environmental Sciences, 8(2): 185-188.

Rabbi, A.K.M.Z., A.K. Paul and Sarker, J.R. 2011. Effects of nitrogen and molybdenum on the growth and yield of garden pea (Pisum sativum L.)IJBSM, 2(2): 230-235. 
Reda A. 2015. Lentil (Lens culinaris Medikus): Current status and future prospect of production in Ethiopia. Adv. Plants Agric. Res., 2: 40.

Roy, A., S.S. Aich, M.K. Bhowmick, and Biswas, P.K. 2009. Response of lentil varieties to sowing time in plains of West Bengal. Journal of crop and weed, 5 (2): 92-94.

Saxena, M.C. and Hawtin, G.C. 1981. Morphology and growth patterns. In: Lentils (eds C. Webb \& G.C Hawtin). Royal commonwealth Agricultural.

Sharma, B.C. and Sharma, S.C. 2004. Integrated nutrient management in lentil. Adv. Plant Sci., 17(1): 195-197.
Sharma, R.K. 1999. Chemical fertilizers can increase productivity in legumes Crop research, 18(1): 159-160.

Singh, O.N., M. Sharma, and Dash, R. 2003. Effect of seed rate, phosphorus and FYM application on growth and yield of bold seeded lentil. Indian J. Pulses Res., 16(2): 116-118.

Togay, Y., N. Togay, y. Dogan, and Ciftici, V. 2005. Effects of nitrogen levels forms on the yield and yield components of lentil (Lens culinaris Medic.). Asian Journal of Plant Sciences, 4(1): 64-66.

\section{How to cite this article:}

Kaneez Fatima, S.A. Ganie, Yogesh Kumar, T.H. Masoodi and Ali Shah. 2018. Effect of Organic and Inorganic Fertilizer Doses on Growth and Yield of Lentil under Cold Arid Conditions of Ladakh. Int.J.Curr.Microbiol.App.Sci. 7(11): 1449-1455. doi: https://doi.org/10.20546/ijcmas.2018.711.167 